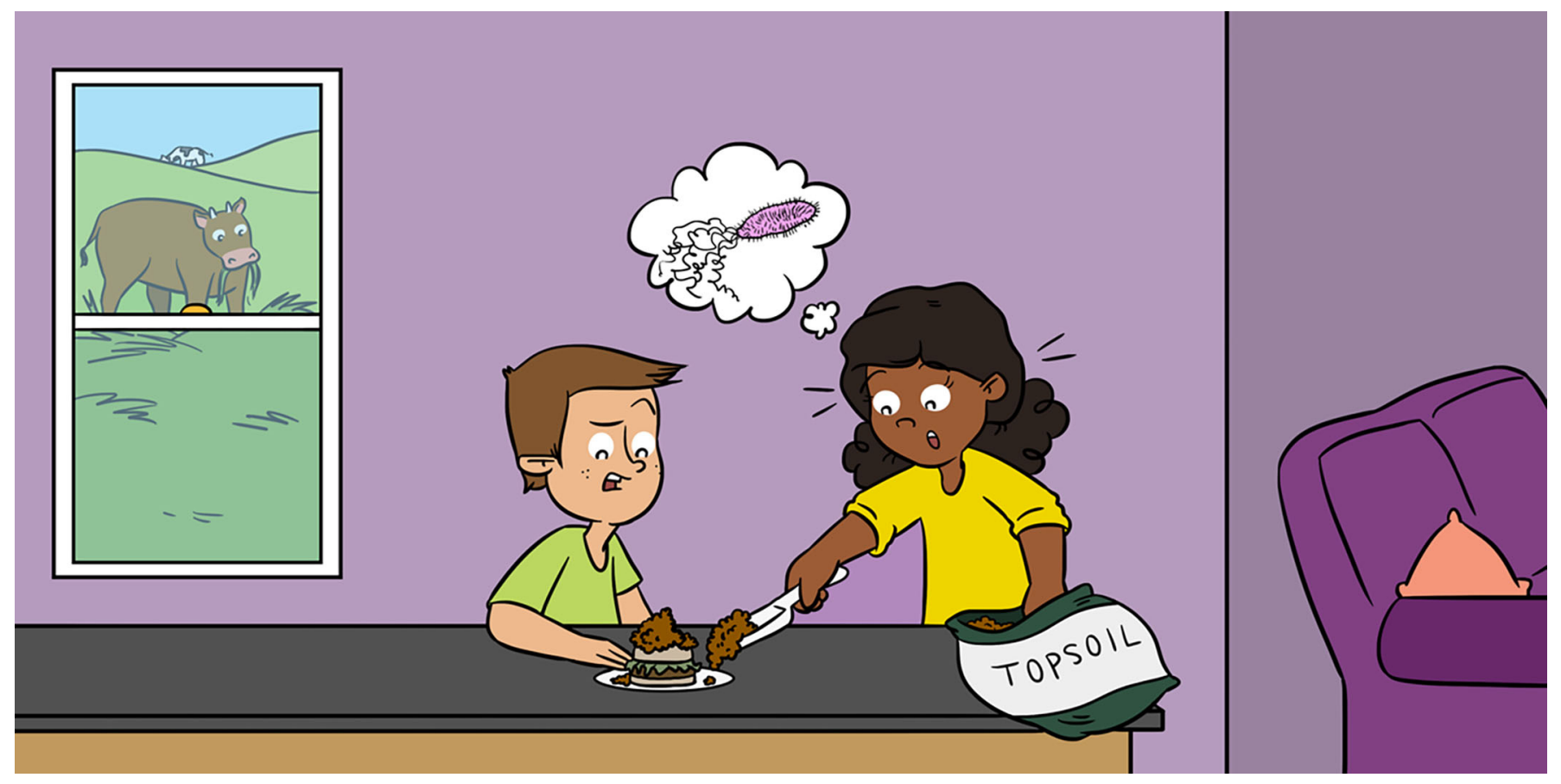

\title{
BACTERIA IN SOIL KEEP YOUR HAMBURGER "HEALTHY"
}

\section{Stephanie D. Jurburg *}

German Centre for Integrative Biodiversity Research (iDiv), Leipzig, Germany

\section{YOUNG REVIEWERS:}

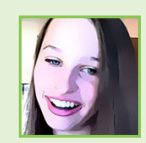

MADDIE

AGE: 15

MATÍAS

AGE: 14

TACY

AGE: 13
In 1993, an outbreak of the bacterium Escherichia coli made over 700 people ill across the United States. A special kind of E. coli, called strain O157:H7, inhabits the guts of cattle and spreads to water and compost through cow manure. The strain 0157:H7 can survive for many months in the water or compost, until it reaches humans through meat or vegetables, causing disease. However, E. coli survives a much shorter time in the soil because it must compete with the many kinds of bacteria already present there. To soil bacteria, strain 0157:H7 is an invader, and invaders depend on the "leftovers" of the native organisms to survive. In more diverse communities, fewer resources are left behind, and it is harder for organisms to invade. This is why E. coli O157:H7 is least successful in soil, the most diverse environment on Earth, and it is one of many reasons why soil bacteria are important for our health. 


\section{STRAIN}

A subtype of a bacterial species that has slight differences in its genes from other strains in the same species.

\section{GENE}

A DNA segment containing instructions for building a protein.

\section{ESCHERICHIA COLI ATTACKS!}

In 1993, an outbreak of the bacterium Escherichia coli caused over 700 people to become seriously ill across the United States. The culprit was uncooked beef patties. Thirteen years later, another E. coli outbreak caused massive recalls of prepackaged spinach across the country. This time, the source was a cattle ranch next to a spinach farm. Since then, E. coli outbreaks have started from the consumption of cheese, onions, soy, and most recently, romaine lettuce. These outbreaks were always caused by the same bacterium: E. coli strain O157:H7. Who is this bacterium and why is it still causing disease outbreaks? Keep reading to learn more!

\section{THE HISTORY AND TRAITS OF E. COLI}

Most of the bacteria we know about today were discovered in the last 10 years. However, E. coli is the exception. This bacterium was discovered in the colon of healthy humans in 1885 , by pediatrician Theodor Escherich, after whom the bacterium is named. Coli refers to their habitat, the colon. Because it grows so well in the laboratory, microbiologists have continued to study $E$. coli to understand how bacteria grow and respond to their surroundings.

Many of the characteristics that make E. coli so attractive as a study organism also make this bacterium stand out. First, E. coli grows very well if it is given the right food sources-and there are many food sources that are "right" for this bacterium. With enough food, E. coli can grow very quickly: from a single cell to a million cells within 7 hours! Second, bacteria can change their genes, and E. coli is especially good at this (Figure 1). Genes are the cell's instruction manual, and unlike larger organisms like animals, bacteria can trade genes with each other, receive genes from a virus, or pick up genes from the environment. When a bacterium changes its genes, its behaviors and abilities change too, and its descendants, which inherit the same new genes, become members of a specific strain-much like you are a member of your family and share many characteristics with them. Instead of family names, strains are usually identified by a code name of letters and numbers, like O157:H7.

\section{THE SUPER STRAIN 0157:H7}

Thousands of $E$. coli cells from different strains live in the healthy human gut and protect us from other pathogenic, or disease-causing, bacteria like Salmonella. But that is not what strain O157:H7 does. First discovered in 1983, E. coli strain O157:H7 now infects $~ 73,000$ people a year in the United States alone [1]. What makes this strain unique is the set of genes it has acquired: one set of genes gives strain O157:H7 the ability to produce Shiga toxin, which is the poisonous substance 


\section{Figure 1}

Bacteria, unlike most other organisms, can change their genes. (A) Escherichia coli strain O157:H7 has genes that were left behind by a virus that infected it. (B) O157:H7 has also taken up genes from the environment. Bacteria can also get genes from other bacteria.

\section{PATHOGEN}

An organism that can cause disease.

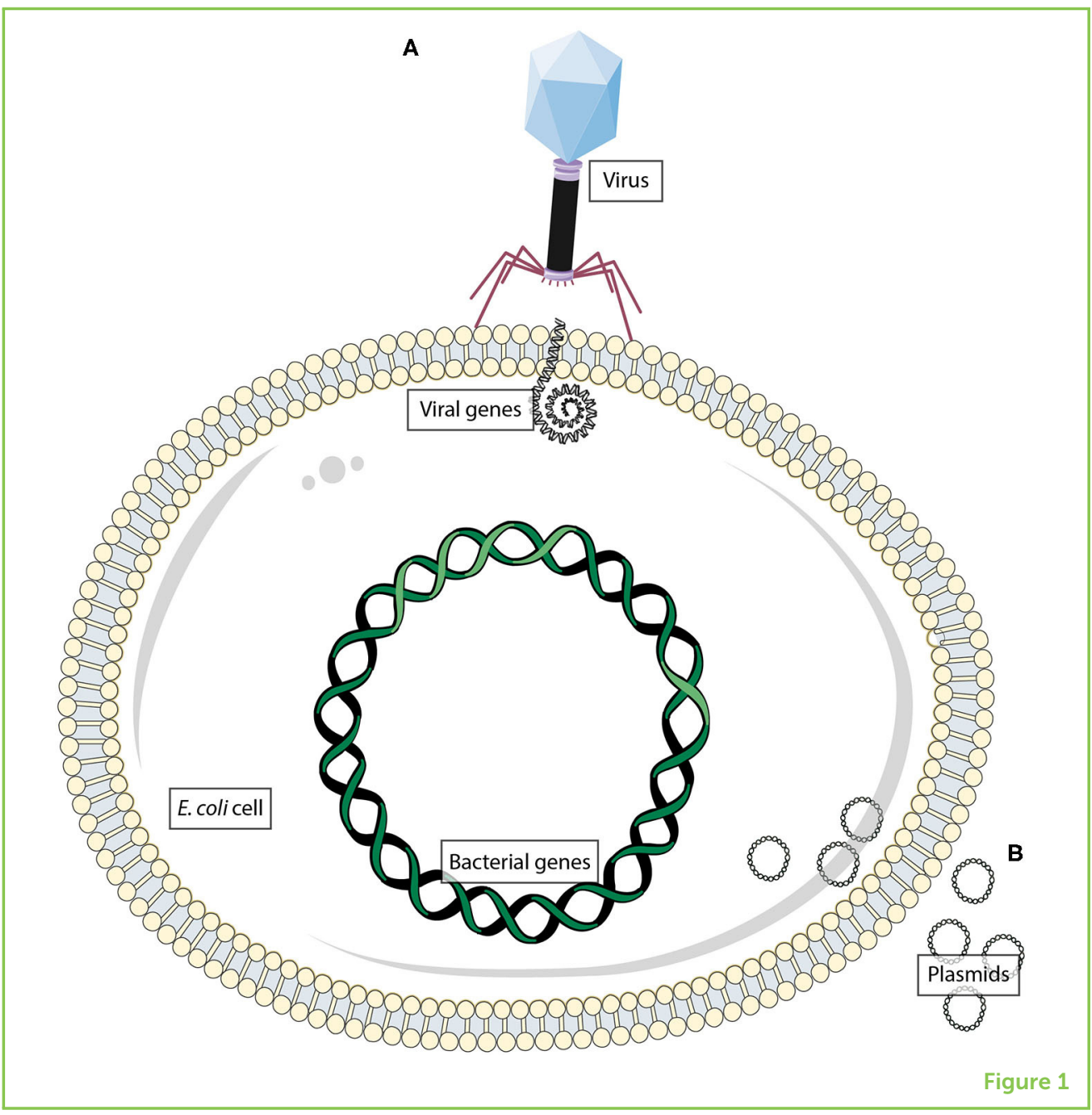

that makes infected people sick. Producing poison is not quite enough to become a threat to our health. Strain O157: $\mathrm{H} 7$ also behaves in a way that makes it a pathogen: it actively tries to spread. Not all E. coli strains do this. This spreading behavior is also a result of genes picked up from the environment (Figure 1).

Since 1993, there have been almost yearly outbreaks of disease caused by $0157: H 7$. Why do they still happen? The simple answer is that there are too many ways that $E$. coli can reach your food. If the beef used to make your hamburger came from an infected cow, your burger is probably contaminated, but this is not a problem, because hamburgers are never eaten raw. When you cook your hamburger, the $E$. coli in it is killed by the heat, and the meat is safe to eat. But vegetables like lettuce are often eaten raw, and in that case, the bacteria may be alive when you eat them.

E. coli normally lives in the guts of cattle for weeks to months, where it does not cause disease (Figure 2). The feces of these animals contain many E. coli cells: a single gram of feces from an infected cow can contain over 50 million $E$. coli cells, and it is extremely difficult to get 


\section{Figure 2}

Many pathways to a hamburger. Beef from infected cows ends up in in raw hamburger patties, and Escherichia coli is shed from the cow gut onto the soil as manure, where the native bacteria compete with it. If $E$. coli persists and can grow in the soil, then it may contaminate crops like lettuce, spinach, and onions.

\section{DIVERSITY}

The number of different species in a community.

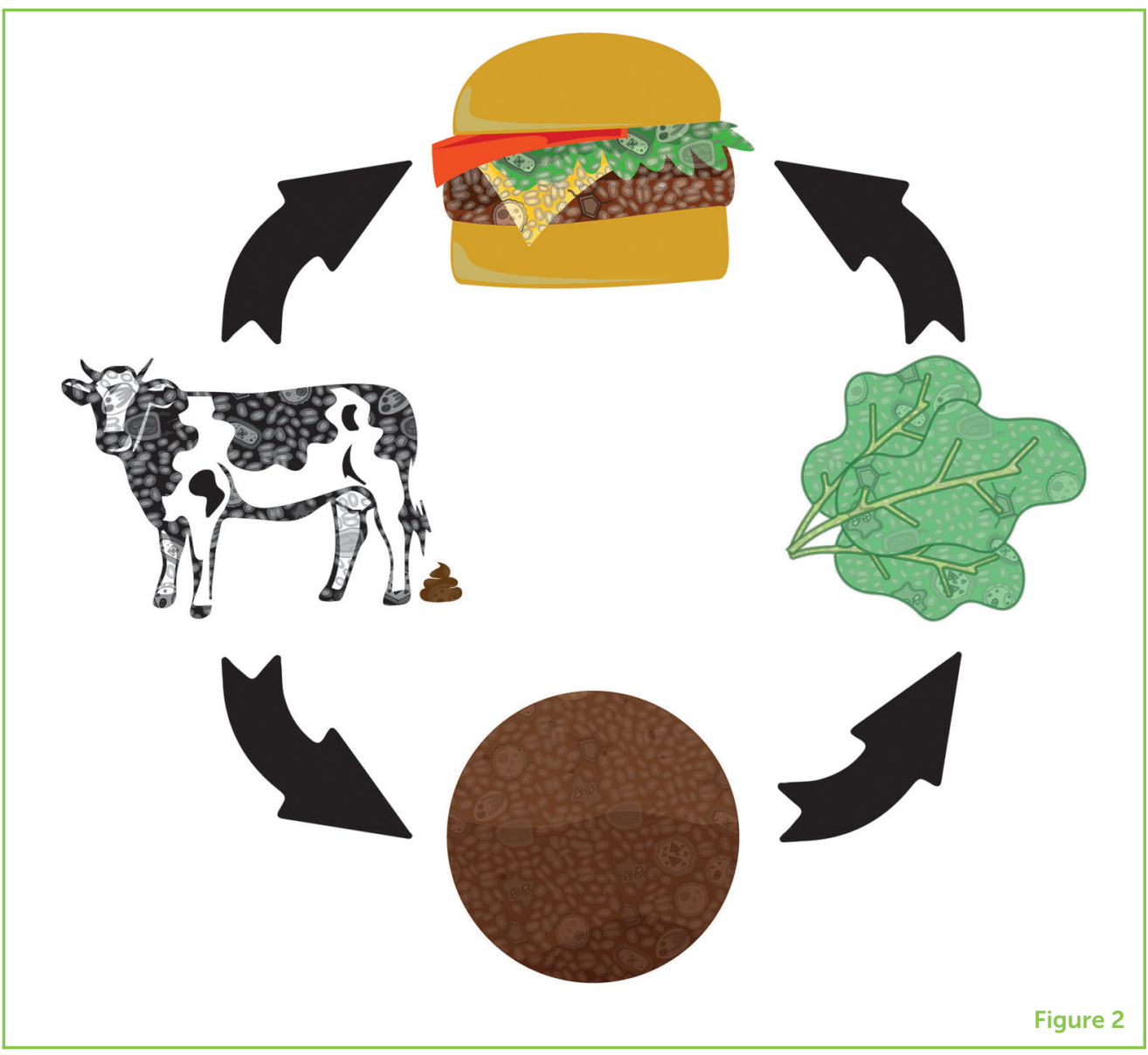

rid of them once they leave the cow as manure. Manure can host these bacteria for over 21 months, giving the bacteria plenty of opportunity to reach the soil. If the manure reaches the water, then the bacteria may survive there for more than 8 months, and during this time, they may also get into the soil, when the water is used to irrigate crops. Once in the soil, E. coli may contact crop plants, result in contaminated fruits and vegetables.

\section{SOIL BACTERIA, A SOLUTION}

Given how long these bacteria can live and how easily they spread, why is $E$. coli relatively rare? The answer: soil bacteria. To contaminate our vegetables, $E$. coli must survive in the soil, but its ability to do so is limited. In soil, E. coli can only survive for 3 months. Scientists think that the diversity of soil bacteria, or the number of different kinds of bacteria naturally living there, make all the difference [2]. No environment is more diverse than soil. A single handful of soil can contain 10,000 different bacteria [3], and very often, many of them are non-infectious strains of $E$. coli. In several experiments, scientists have shown that the more diversity a soil has, the harder it is for dangerous bacteria to successfully invade it. The reason for this seems to be the availability of resources that the invading 
bacteria need to survive [4]. Resource consumption for bacteria is similar to food preferences in animals, and different strains of bacteria consume different resources. When an environment like the soil has a high diversity of natural bacteria, the bacterial community consumes a wide range of resources, leaving nothing behind. When $E$. coli lands on this environment, it is not able to feed or grow, and so it dies. Less diverse groups of bacteria cannot consume all the resources, leaving "leftovers," which $E$. coli can use to grow and spread.

\section{HOW ANTIBIOTICS HELP E, COLI}

So, now you know that the diversity of bacteria in soil is important because it ensures that there are few resources left for disease-causing bacteria to use. Unfortunately, soil bacteria are constantly threatened by antibiotics. Humans use antibiotics to combat diseases in animals and in themselves, but soils are exposed to antibiotics in ways we did not initially expect. Consider how soil can become contaminated with the pathogenic $E$. coli strain: cattle feces. To prevent disease outbreaks, cows often receive large amounts of antibiotics. These are not fully used up by their bodies and can be released into the environment through the cow's urine and feces. But that is just the beginning. Sewage contains lots of antibiotics released in the same way by humans and by the water from fish farms, which is also high in antibiotics. These waters mix into rivers, which are then used to irrigate soils for agriculture. Once the antibiotics reach the soil, they kill most of the good soil bacteria, leaving behind resources that pathogenic bacteria can use to grow and multiply, potentially spreading disease. A growing group of countries around the world have created laws to limit the use of antibiotics on animals like cattle, as a way to reduce the spread of antibiotics in the environment and to improve the health of their citizens but also of wildlife.

\section{BACTERIA: THE TINY ROAD AHEAD}

Humans have known that bacteria cause diseases since the 1800s, but we are still learning the ways in which bacteria can prevent diseases. In fact, we have only started to see the full extent of bacterial diversity over the past 20 years. We used to think that a clean environment was a sterile one, without any bacteria. As we gather more and more information about the bacterial world, our definition of what is "clean" is changing, from an emphasis on the lack of bacteria to a focus on having the "right" bacteria who can prevent the pathogenic bacteria from successfully invading. We now know that bacteria are everywhere, and it is not possible to live without them. Our research is shifting from trying to keep our world free of bacteria, to learning 
how to select the right ones: those that help our environments and our bodies to stay healthy. There are still many unanswered questions. For example, who are the "right" bacteria, and what makes them so special?

\section{REFERENCES}

1. Lim, J. Y., Yoon, J. W., and Hovde, C. J. 2013. A brief overview of Escherichia coli O157:H7 and its plasmid O157. J. Microbiol. Biotechnol. 20:5-14. doi: 10.4014/ jmb.0908.08007

2. Thakur, M. P., Putten, W. H., Cobben, M. M. P., Kleunen, M., and Geisen, S. 2019. Microbial invasions in terrestrial ecosystems. Nat. Rev. Microbiol. 17:621-31. doi: 10.1038/s41579-019-0236-z

3. Le Roux, X., Recous, S., and Attard, E. 2011. "Soil microbial diversity in grasslands," in Grassland Productivity and Ecosystem Services, eds G. Lemaire, J. Hodgson, and A. Chabbi (CAB International). p. 158-65.

4. Eisenhauer, N., Schulz, W., Scheu, S., and Jousset, A. 2013. Niche dimensionality links biodiversity and invasibility of microbial communities. Funct. Ecol. 27:282-8. doi: 10.1111/j.1365-2435.2012.02060.x

SUBMITTED: 26 March 2020; ACCEPTED: 26 October 2020; PUBLISHED ONLINE: 13 November 2020.

EDITED BY: Malte Jochum, German Centre for Integrative Biodiversity Research (iDiv), Germany

CITATION: Jurburg SD (2020) Bacteria in Soil Keep Your Hamburger "Healthy". Front. Young Minds 8:545905. doi: 10.3389/frym.2020.545905

CONFLICT OF INTEREST: The author declares that the research was conducted in the absence of any commercial or financial relationships that could be construed as a potential conflict of interest.

COPYRIGHT $\odot 2020$ Jurburg. This is an open-access article distributed under the terms of the Creative Commons Attribution License (CC BY). The use, distribution or reproduction in other forums is permitted, provided the original author(s) and the copyright owner(s) are credited and that the original publication in this journal is cited, in accordance with accepted academic practice. No use, distribution or reproduction is permitted which does not comply with these terms.

\section{YOUNG REVIEWERS}

\section{MADDIE, AGE: 15}

My name is Maddie. I am 15 years old, and live near San Francisco. 

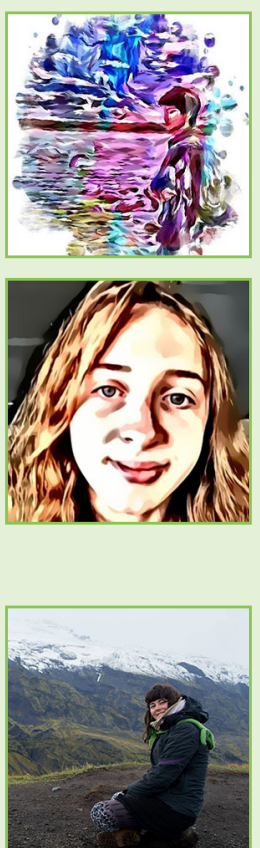

\section{MATÍAS, AGE: 14}

I am a 14 years old who loves science, programming, Vikings, mythology, Jiu-Jitsu, rock and roll, singing, and playing drums.

\section{TACY, AGE: 13}

Hi I am Tacy. I am 13, and live near San Francisco. I like drawing, videogames, and playing guitar.

\section{AUTHOR}

\section{STEPHANIE D. JURBURG}

Stephanie Jurburg is an enthusiast of all things tiny. For nearly a decade, she has studied how the bacteria living in and around us shape our world, making us healthy or unhealthy and keeping our soils fertile. She is particularly interested in how communities of bacteria change over time, and how they recover when they are disturbed. Currently, she is a researcher at the German Centre for Integrative Biodiversity Research (iDiv), where she studies how the bacterial communities in different environments are alike. *s.d.jurburg@gmail.com 